
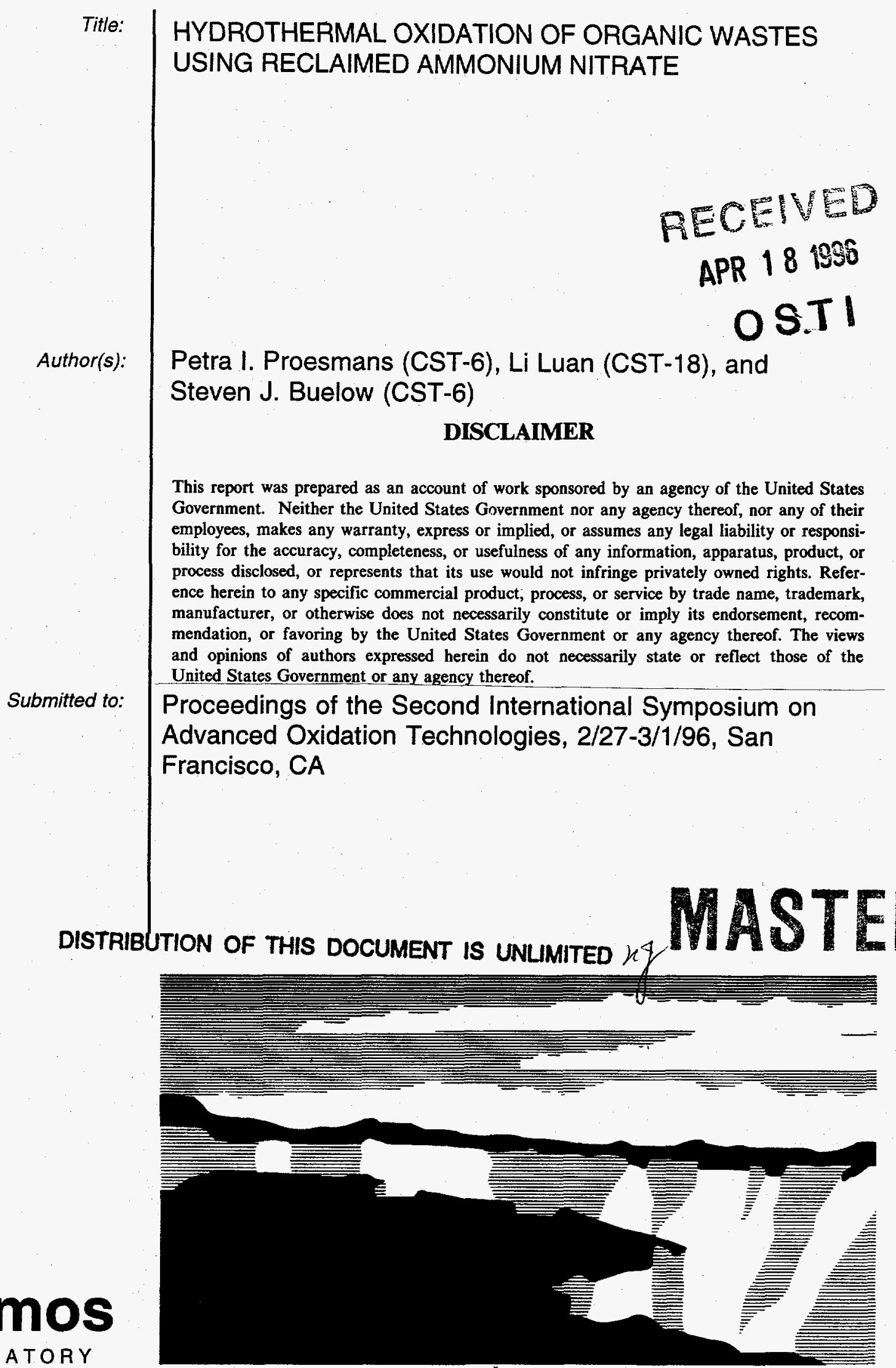

Los Alamos National Laboratory, an affirmative action/equal opportunity employer, is operated by the University of California for the U.S. Department of Energy under contract W-7405-ENG-36. By acceptance of this article, the publisher recognizes that the U.S. Government retains a nonexclusive, royalty-free license to publish or reproduce the published form of this contribution, or to allow others to do so, for U.S. Government purposes. The Los Alamos National Laboratory requests that the publisher identify this article as work performed under the auspices of the U.S. Department of Energy. 


\section{DISCLAIMER}

Portions of this document may be illegible in electronic image products. Images are produced from the best available original document. 


\title{
HYDROTHERMAL OXIDATION OF ORGANIC WASTES USING RECLAIMED AMMONIUM NITRATE
}

\author{
Petra I. Proesmans \\ Los Alamos National Laboratory \\ Chemical Science and Technology Division \\ Chemical Reactions, Kinetics and Dynamics, CST-6 \\ Los Alamos, New Mexico, 87545
}

Li Luan

Los Alamos National Laboratory

Chemical Science and Technology Division

Waste Treatment and Minimization Science and Technology, CST-18

Los Alamos, New Mexico , 87545

\author{
Steven J. Buelow \\ Los Alamos National Laboratory \\ Chemical Science and Technology Division \\ Chemical Reactions, Kinetics and Dynamics, CST-6 \\ Los Alamos, New Mexico, 87545
}

\section{Abstract}

Ammonium Nitrate was investigated as an oxidizing agent for methanol, acetic acid and phenol. High removal of organic, ammonia and nitrate was achieved at stoichiometric concentrations. The oxidation of ammonia by nitrate was much faster than the oxidation of either methanol or acetic acid. Phenol, however, was in strong competition with ammonia for the oxidizer (nitrate). Nitrogen products included $\mathrm{N}_{2}, \mathrm{~N}_{2} \mathrm{O}, \mathrm{NO}_{2}{ }^{-}$as well as toxic $\mathrm{NO}$ and trace amounts of $\mathrm{NO}_{2}$. Carbon products were $\mathrm{CO}_{2}, \mathrm{HCO}_{3}^{-}, \mathrm{CO}_{3}^{2-}$, and $\mathrm{CO}$. 


\section{Introduction}

Ammonium nitrate is being studied as an alternative for ammonium perchlorate as an oxidizing agent in Department of Defense 1.1 and 1.3 rocket propellants. Use of ammonium nitrate would eliminate the $\mathrm{HCl}$ produced by ammonium perchlorate upon thermal decomposition. To stabilize the ammonium nitrate, which suffers from phase instability, potassium dinitramide (KDN) is added. This increased use of ammonium nitrate will ultimately create a need for environmentally responsible processes to reuse ammonium nitrate extracted from demilitarized rocket motors.

The objective of this research was to provide a preliminary evaluation of ammonium nitrate as an oxidizer for the destruction of organic wastes under hydrothermal conditions. Experiments examined the hydrothermal oxidation of three organic model compounds using ammonium nitrate as an oxidizer. Methanol, acetic acid and phenol were selected as the model compounds to represent various type of waste constituents, i.e. alcohol, organic acid, and aromatic compounds. Experiments were performed at varying temperatures, residence times, ammonium nitrate and carbon concentrations. Gaseous, liquid, and solid effluents were collected and analyzed. The results of experiments are used to provide an evaluation of ammonium nitrate, and ultimately KDN-phase stabilized ammonium nitrate (PSAN), as an oxidizer for organic wastes in hydrothermal treatment systems, and to develop a mechanism for the reactions of organic compounds with nitrates under hydrothermal conditions.

\section{Experimental}

Bench scale flow reactors were uniformly heated in a fluidized sandbath. The reactor consisted of a coiled high pressure tube (Alloy $625,0.65 \mathrm{~cm} \mathrm{OD,} 0.21 \mathrm{~cm}$ id. $318 \mathrm{~cm}$ long for the experiments of the oxidation of ammonia by nitrate; $S S 316,1 \mathrm{~cm} \mathrm{OD,} 0.32 \mathrm{~cm} \mathrm{id,} 106 \mathrm{~cm}$ long, Ti lined, for the remainder of the experiments). Reagents were mixed prior to heating and pumped by HPLC pumps. A counter flow heat exchanger, placed at the exit of the reactor, rapidly quenched the reactions. After cooling, the reactor effluent was filtered. A backpressure regulator controlled the pressure in the system. Nine thermocouples monitored the surface temperature of the reactor and the fluid temperature. Transducers placed before the mixing tee and the back pressure regulator measured the pressure. A more detailed description of this reactor is given elsewhere 6 . 
Feed solutions were prepared using analytical grade methanol, acetic acid, phenol, concentrated ammonium hydroxide (30 wt.\%) and de-ionized water. Gaseous products were analyzed using gas chromatograph (GC) equipped with a dual column (PoraPLOT U and molecular sieve $5 \AA$ ) and thermal conductivity detectors. Helium was used as the carrier gas. The gases that could be detected included $\mathrm{O}_{2}, \mathrm{~N}_{2}, \mathrm{~N}_{2} \mathrm{O}, \mathrm{CH}_{4}, \mathrm{C}_{2} \mathrm{H}_{6}, \mathrm{CO}, \mathrm{CO}_{2}$. Larger hydrocarbon gases $\left(\mathrm{C}_{3}\right.$ or greater) could not be analyzed on this system. Infrared spectroscopy was used to analyze gas samples for $\mathrm{NO}_{\mathrm{X}}$, volatile organics, $\mathrm{HCN}$, etc. The IR spectra were measured over a spectral range $450 \mathrm{~cm}^{-1}$ to $4000 \mathrm{~cm}^{-1}$ using either a Bio-Rad or Mattson FT-IR spectrometer equipped with a three meter path length gas cell. A pH electrode was used to measure feed and effluent $\mathrm{pH}$ levels. Hydrogen peroxide concentrations were measured by titration with $\mathrm{KMnO}_{4}$. Nitrite, nitrate, formate, acetate ions were analyzed by ion chromatography (IC). Ammonium/ammonia was analyzed with an ion selective electrode or IC. Total inorganic carbon (TIC) and Total organic carbon (TOC) were measured using a carbon analyzer. An inductively coupled plasma (ICP) spectrometer was used to determine the concentration of corrosion produced metals $(\mathrm{Fe}, \mathrm{Cr}, \mathrm{Mo}$, $\mathrm{Ni}$ ) contained in the effluent.

\section{Oxidation of Ammonia by Nitrate}

The reaction of ammonia with nitrate was investigated near $500^{\circ} \mathrm{C}$ and 375 bar and at residence time of 50 seconds. Nitrate concentrations were $0.5 \mathrm{M}$, while ammonia concentrations were varied from 0.6 to $1.6 \mathrm{M}$. Figure 1 shows the removal of ammonia and nitrate for varying initial concentration ratios. The data indicates that for an initial $\mathrm{HNO}_{3}$ concentration of $0.5 \mathrm{~mol} / \mathrm{l}$, a ratio of $\mathrm{HNO}_{3}$ to $\mathrm{NH}_{3}$ of near 0.65 produces nearly complete reaction of both species.

The products of reaction were $\mathrm{NO}_{2}^{-}, \mathrm{N}_{2}$ and $\mathrm{N}_{2} \mathrm{O}$. $\mathrm{NO}_{\mathrm{X}}$ products in the gaseous effluent were not detected by IR spectroscopy. The ratio of $\mathrm{N}_{2}$ to $\mathrm{N}_{2} \mathrm{O}$ was 3.9 on average and did not depend significantly on initial nitrate concentration. At $\mathrm{NO}_{3}-/ \mathrm{NH}_{3}$ ratios higher than $0.65, \mathrm{NO}_{2}^{-}$was produced by the reaction and present in the effluent along with unreacted $\mathrm{NO}_{3}{ }^{-}$. For $\mathrm{HNO}_{3} / \mathrm{NH}_{3}$ ratios below 0.65 , only unreacted $\mathrm{NH}_{3}$ was present in the effluent.

Thermal decomposition of neat ammonium nitrate has been the subject of investigation for many years ${ }^{1}$. Reaction products, usually $\mathrm{N}_{2} \mathrm{O}, \mathrm{N}_{2}$ and $\mathrm{NO}_{X}$, depend significantly on the reaction conditions (temperature, pressure and contact of the samples). A free radical mechanism was proposed for high temperature reactions $\left(>290^{\circ} \mathrm{C}\right.$ ) while an ionic mechanism was proposed at relative low temperatures $2,3,4$. Related work in the supercritical water includes the oxidation of ammonia by oxygen or hydrogen peroxide. In these systems, very low conversions were achieved 
even at high temperatures $(>550) 5$. Oxidation of ammonia by alkali nitrate was studied at low concentrations 6 . A detailed mechanistic investigation is not currently available. The amide radical $\cdot \mathrm{NH}_{2}$ was suggested to be the key intermediate for the destruction of ammonia.

\section{Oxidation of Methanol, Acetic Acid and Phenol by Ammonium Nitrate}

Initially, the effect of temperature and residence time on the oxidation of methanol, acetic acid and phenol was studied. Temperatures varied from $400^{\circ} \mathrm{C}$ to $500^{\circ} \mathrm{C}$, and residence times from 10 to 140 seconds. The oxidation occurs rapidly at temperatures above $400^{\circ} \mathrm{C}$ and pressures near 345 bar. Residence times greater than 10 seconds at these conditions produced greater than $99 \%$ conversion of the organic carbon to products. The rates of oxidation were sufficiently high ( $\mathrm{keffective}>0.5 \mathrm{sec}^{-1}$ ) that the kinetics of the reactions could not be elucidated with the reactor systems used for this study.

Further experiments were conducted at nominal temperatures and pressures of $500^{\circ} \mathrm{C}$ and $345 \mathrm{bar}$ The methanol concentrations ranged from $0.2 \mathrm{~mol} / /$ to $1.8 \mathrm{~mol} / \mathrm{l}$, acetic acid concentrations from $0.15 \mathrm{~mol} / /$ to $0.56 \mathrm{~mol} / \mathrm{l}$ and phenol concentrations from $0.03 \mathrm{~mol} / \mathrm{l}$ to $0.15 \mathrm{~mol} / \mathrm{l}$. Residence times of 30 to 40 seconds were registered.

Figures 3, 4 and 5 show the concentration of organic carbon and ammonia in the effluent as a function of the carbon content and ammonia concentration in the feed solution. Both influent and effluent concentrations are expressed as "reducing equivalent", calculated as the concentration in mol// multiplied by the chemical oxygen demand (COD). The COD for ammonia is estimated to be 1.5 , assuming complete oxidation to $\mathrm{N}_{2}\left(\mathrm{NH}_{3}+1.5 \mathrm{O}->0.5 \mathrm{~N}_{2}+1.5 \mathrm{H}_{2} \mathrm{O}\right)$. The COD for the organic compounds is also calculated by assuming complete oxidation to $\mathrm{CO}_{2}$, yielding a $\mathrm{COD}$ of 3 for methanol, 2 for acetic acid, and 2.33 for phenol.

The graphs indicate that for a $1 \mathrm{~mol} / \mathrm{l}$ ammonium nitrate solution, the nitrate concentration becomes insufficient for complete oxidation of both ammonia and methanol at a the reducing equivalent concentration of circa $2.5 \mathrm{~mol} / \mathrm{l}$ (corresponding to a carbon concentrations of $0.5 \mathrm{~mol} / \mathrm{l}$ as methanol, $0.75 \mathrm{~mol} / \mathrm{h}$ as acetic acid and $0.64 \mathrm{~mol} / \mathrm{l}$ as phenol). This agrees with the concentration predicted from the $2.5 \mathrm{~mol} / \mathrm{l}$ oxidizing equivalents of $1 \mathrm{~mol} / \mathrm{l} \mathrm{HNO}_{3}\left(\mathrm{HNO}_{3}-->0.5 \mathrm{~N}_{2}+0.5 \mathrm{H}_{2} \mathrm{O}\right.$ $+2.5 \mathrm{O}$ ). At higher carbon concentrations, the reducing equivalents of carbon in the effluent increases linearly. For methanol and acetic acid (Figures. 1 and 2), the reducing equivalent as carbon increases with a slope close to 1 , while the increase of ammonia in the effluent is neglectible. When the organic reducing level is greater than $1.0 \mathrm{~mol} / \mathrm{l}$, the organic must compete with ammonia for the nitrate oxygen. A slope of 1.0 is expected for the sum of all reducing 
equivalents in the eflluent (as carbon, ammonia or $\mathrm{H}_{2}$ ), when no other oxidation mechanism of the organic compound occurs. Hydrolysis experiments showed that hydrolysis and/or pyrolysis reactions were not important reaction pathways for methanol, acetic acid, and phenol destruction at the temperatures and residence time examined in this study.

However, Figure 5 shows that phenol reacts with nitrate nearly as rapidly as ammonia. The limited data set shows that, at excess reducing levels, the concentration of ammonia reducing equivalents in the effluent initially increases at about the same rate as the phenol reducing equivalent. Thereafter, ammonia seems to reach an equilibrium concentration of about $2.5 \mathrm{~mol} / \mathrm{l}$ reducing equivalent $(0.17 \mathrm{~mol} / \mathrm{l} \mathrm{NH} 3)$. If the carbon reacts 1.5 times faster than the ammonia with nitrate, the concentration of ammonia will reach about a concentration of $0.17 \mathrm{~mol} / \mathrm{l}$.

As may be concluded from the figures, phenol appears to be more reactive with nitrate than either methanol or acetic acid. Similar findings were reported in the literature for the oxidation of organic compounds by oxygen. Previous studies compared the relative rates of oxidation reactions (with oxygen) between primary and secondary alcohols, and acetic acid and methanol. They concluded that primary alcohols (ethanol, 1-propanol) oxidized most rapidly, followed by the secondary alcohols (2-propanol). Methanol and acetic acid oxidized most slowly 7 . In a comparison of the oxidation of acetic acid and 2,4-dichlorophenol by hydrogen peroxide and oxygen, much higher conversions were obtained for the aromatic compound compared to acetic acid, both with oxygen and hydrogen peroxide as an oxidizer 8 .

Carbon products in the liquid phase were found to be mainly the unreacted compounds (methanol, acetic acid or phenol, for the experiments at substoichiometric nitrate concentrations), trace amounts of formate (for the acetic acid experiments), carbonate and bicarbonate. Gaseous carbon products were $\mathrm{CO}_{2}$ and $\mathrm{CO}$. Figures 5 through 7 show the correlation between the hydrogen and carbon monoxide production and the carbon concentration in the feed. For both methanol and acetic acid oxidation, the hydrogen and carbon monoxide increases simultaneously for a reducing equivalent concentration in the feed of $2.5 \mathrm{~mol} / \mathrm{l}$ or more. In the case of phenol, hydrogen production is detected for a feed concentration of higher than $2.5 \mathrm{~mol} / \mathrm{h}$, but it slowly diminishes for increasing inlet concentrations.

Nitrogen products in the liquid effluent depended upon the relative concentrations of all components in the initial feeds. The products included small amounts of nitrate, nitrite and/or ammonia. Gaseous nitrogen products included $\mathrm{N}_{2} \mathrm{O}, \mathrm{N}_{2}, \mathrm{NO}$ and trace amounts of $\mathrm{NO}_{2}$. Figures 8 through 10 show the gaseous nitrogen products as a function of the organic carbon content in the 
feed solution. Overall, the $\mathrm{N}_{2}$ production increased, and the $\mathrm{N}_{2} \mathrm{O}$ and $\mathrm{NO}$ production decreased with increasing carbon concentrations. The NO production was the greatest for the oxidation of acetic acid, and minimal for the phenol oxidation. To eliminate the production of $\mathrm{NO}_{\mathrm{X}}$, the use of hydrogen peroxide as a co-oxidant with nitrate was investigated 9 .

\section{Conclusions}

Ammonium nitrate is an effective oxidizer for the tested organic compounds. Reactions were completed within less than 30 seconds at $500^{\circ} \mathrm{C}$ and 345 bar. Oxidation was only limited by the availability of the oxidizing agent. Major reaction products were $\mathrm{N}_{2}, \mathrm{~N}_{2} \mathrm{O}, \mathrm{NO}, \mathrm{CO}_{2}$ (bicarbonate and carbonate). Small amounts of $\mathrm{CO}, \mathrm{H}_{2}$ and residual $\mathrm{NH}_{3}$ and $\mathrm{TOC}$ were detected in the effluent for higher than stoichiometric amounts of organics. Residual nitrate and small amounts of nitrite existed in the effluent when less than stoichiometric organic was present. NO was formed at less than $8 \%$ (of the total $\mathrm{N}$ in the feed solution), and decreased with increasing TOC in the feed. The relative oxidation rate of ammonia by nitrate was comparable to that of phenol and much faster than that of methanol and acetic acid. The phenol oxidation showed distinctly different chemistry from methanol and acetic acid.

Additional experiments were performed investigating the oxidation of methanol, acetic acid and phenol by a co-oxidant system of ammonium nitrate and hydrogen peroxide. The applicability of phase stabilized ammonium nitrate as an oxidizer was also studied. The results are being analyzed and will be published in a forthcoming paper.

\section{Acknowledgments}

We gratefully acknowledge the US Army Corps of Engineer Construction Engineering Research Laboratory for financial support.

\section{References}

1. L.A. Medard. Accidental Explosions. New York: Wiley, 1989, Vol. II, pp. 545-592.

2. W.A. Rosser, S.H. Inami, and H. Wise. "The Kinetics of Decomposition of Liquid Ammonium Nitrate." Journal of Physical Chemistry. Vol. 67, pp. 1753 (1963).

3. K.R. Brower, C.O. Oxley, and Mohan Tewari. "Evidence for Homolytic Decomposition of Ammonium Nitrate at High Temperature." Journal of Physical Chemistry. Vol. 93, pp. 4029-4033 (1989). 
4. A.M. Mearns, and K. Ofosu-Asiedu. "Ammonium Nitrate Formation in Low Concentration Mixtures of Oxides of Nitrogen and Ammonia." Journal of Chemical Technology and Biotechnology. Vol. 43A, pp. 350-354 (1984).

5. W.R. Killilea, K.C. Swallow, and G.T. Hong. "The Fate of Nitrogen in Supercritical Water Oxidation." Journal of Supercritical Fluids. Vol. 5, pp. $72-78$ (1992).

6. P.C. Dell'Orco. "Reactions of Inorganic Nitrogen Species in Supercritical Water." Ph.D. Thesis, The University of Texas at Austin (1994).

7. L.T. Boock, and M.T. Klein. "Lumping Strategy for Modeling the Oxidation of $\mathrm{C}_{1}-\mathrm{C}_{3}$ Alcohols and Acetic Acid in High Temperature Water." Industrial Engineering Chemistry Research. Vol. 32, pp. 2464-2473 (1993).

8. D.S. Lee, and E.F. Gloyna. "Efficiency of $\mathrm{H}_{2} \mathrm{O}_{2}$ and $\mathrm{O}_{2}$ in Supercritical Water Oxidation of 2,4-Dichlorophenol and Acetic Acid." Journal of Supercritical Fluids. Vol. 3, pp. 249-255 (1990).

9. P.I. Proesmans, L. Luan, S.J. Buelow. "Use of Reclaimed Ammonium Nitrate as an Oxidizer for the Hydrothermal Oxidation of Organic Wastes." Los Alamos Unclassified Report, LAUR-95-4138 (1995). 


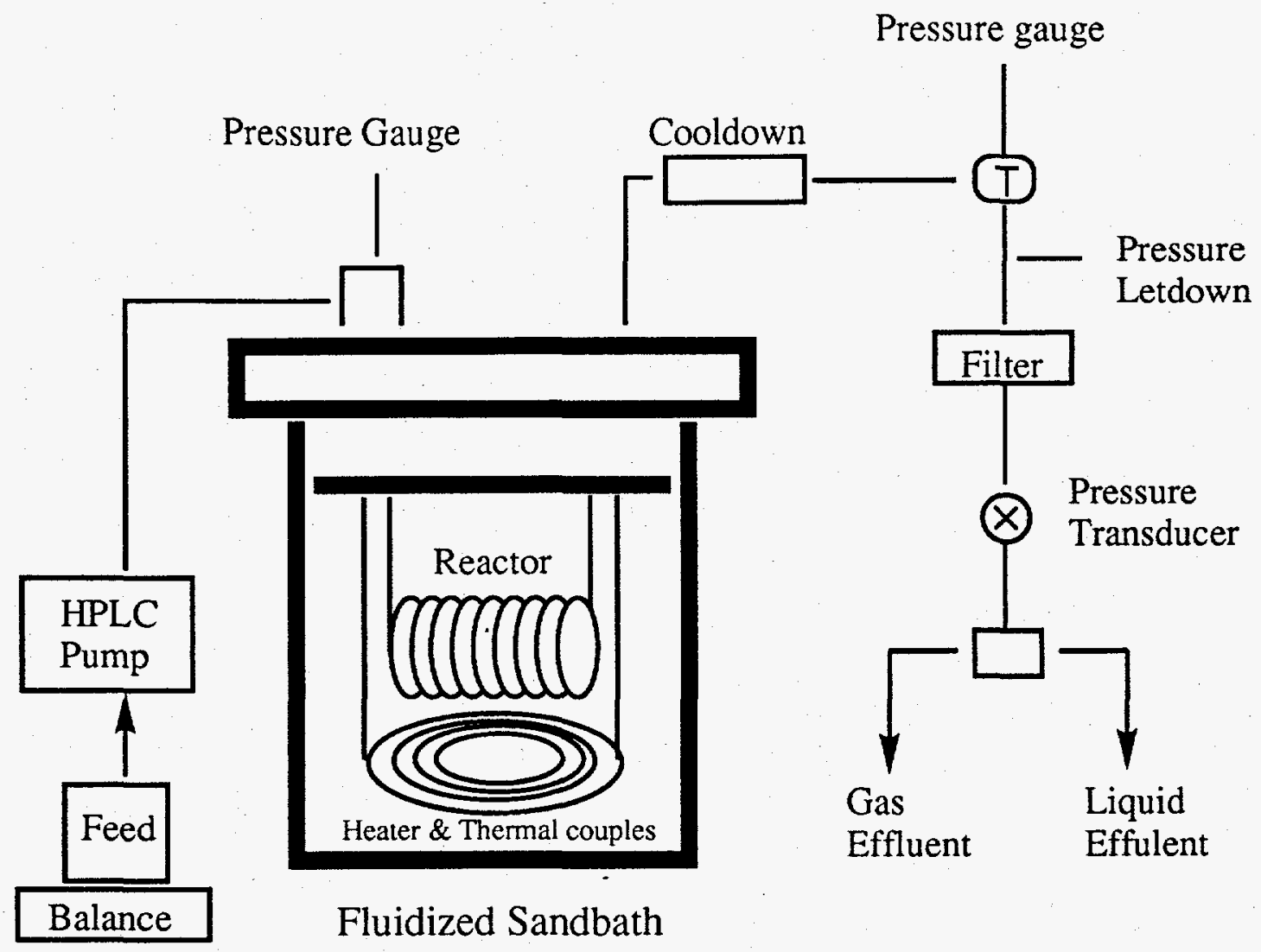

FIGURE 1: Schematic of tubular flow reactor 


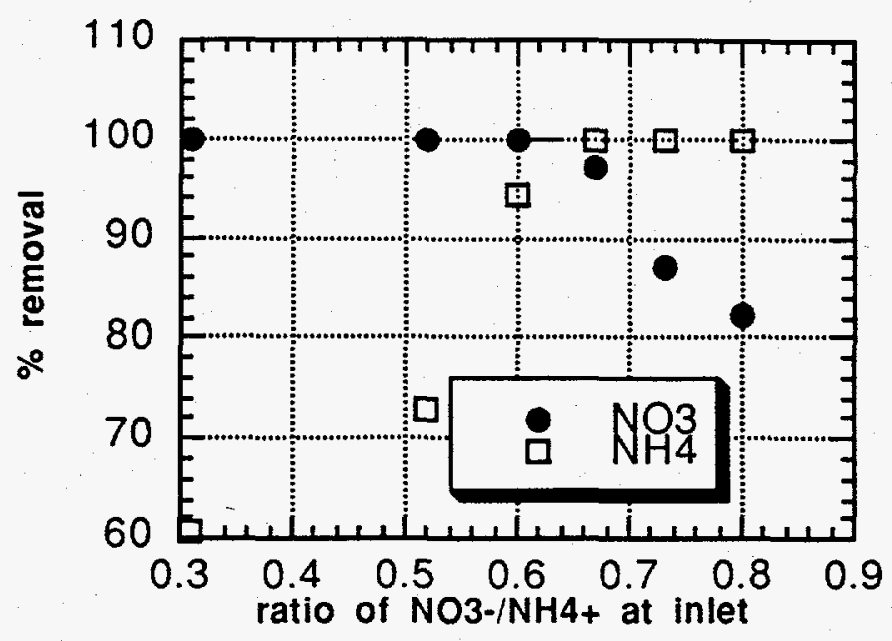

FIGURE 2: Ammonia and nitrate removal for the oxidation of ammnonia by nitrate $(0.5 \mathrm{~mol} / \mathrm{h})$ at $500^{\circ} \mathrm{C}$ and $375 \mathrm{bar}$

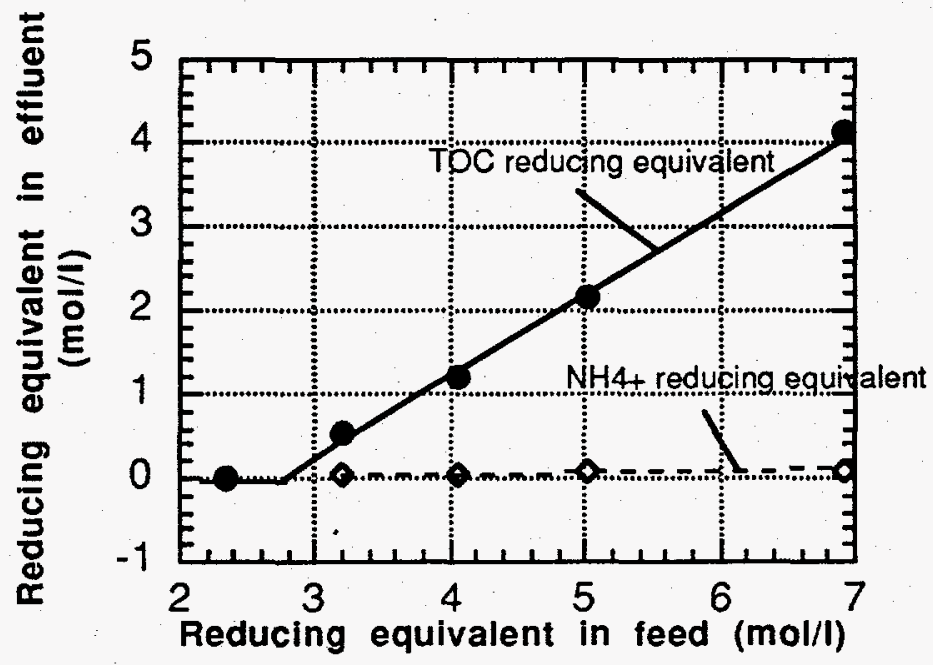

FIGURE 3: Ammonia and carbon reducing equivalent concentrations in effluent for $1 \mathrm{~mol} / \mathrm{l}$ ammonium nitrate with methanol at $500^{\circ} \mathrm{C}$ and 345 bar 


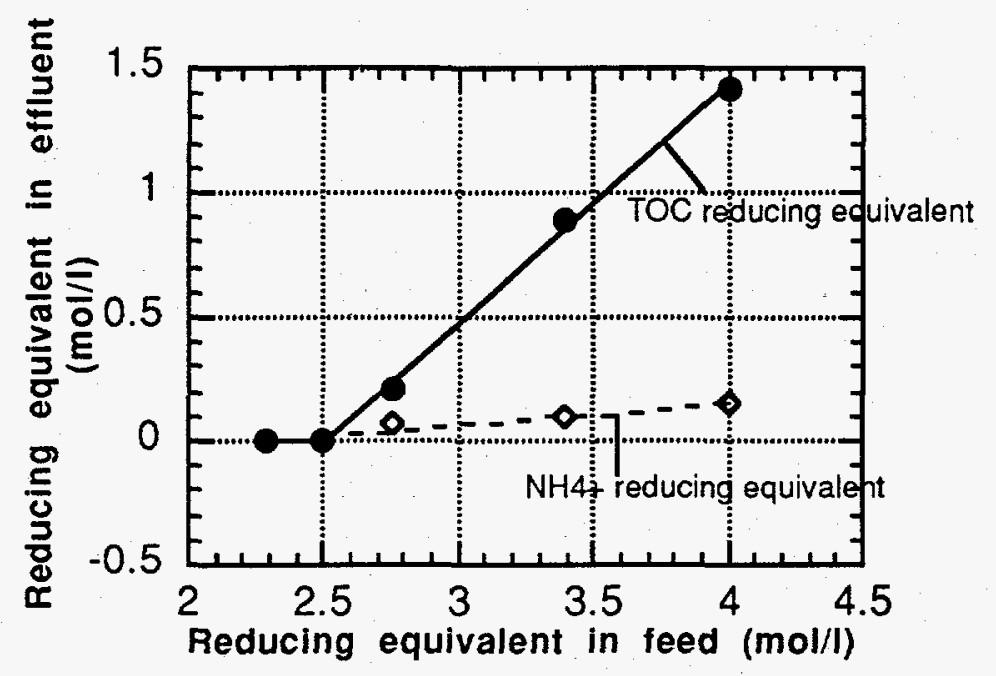

FIGURE 4: Ammonia and carbon reducing equivalent concentrations in effluent for $1 \mathrm{~mol} / \mathrm{h}$ ammonium nitrate with acetic acid at $500^{\circ} \mathrm{C}$ and 345 bar

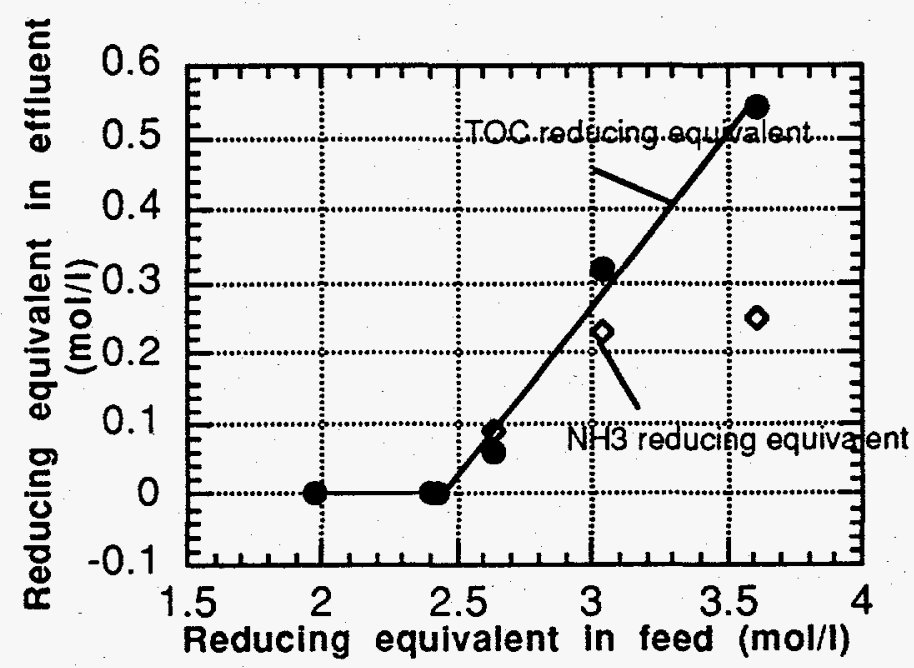

FIGURE 5: Ammonia and carbon reducing equivalent concentrations in effluent for $1 \mathrm{~mol} / \mathrm{l}$ ammonium nitrate with phenol at $500^{\circ} \mathrm{C}$ and $345 \mathrm{bar}$ 


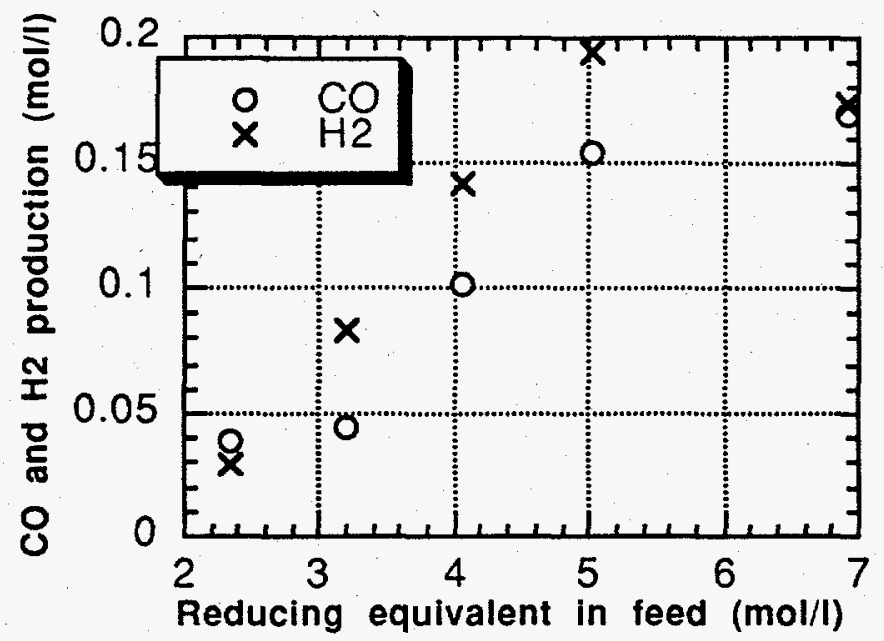

FIGURE 6: Hydrogen and Carbon Monoxide concentrations in effluent for $1 \mathrm{~mol} / \mathrm{l}$ ammonium nitrate with methanol at $500^{\circ} \mathrm{C}$ and 345 bar

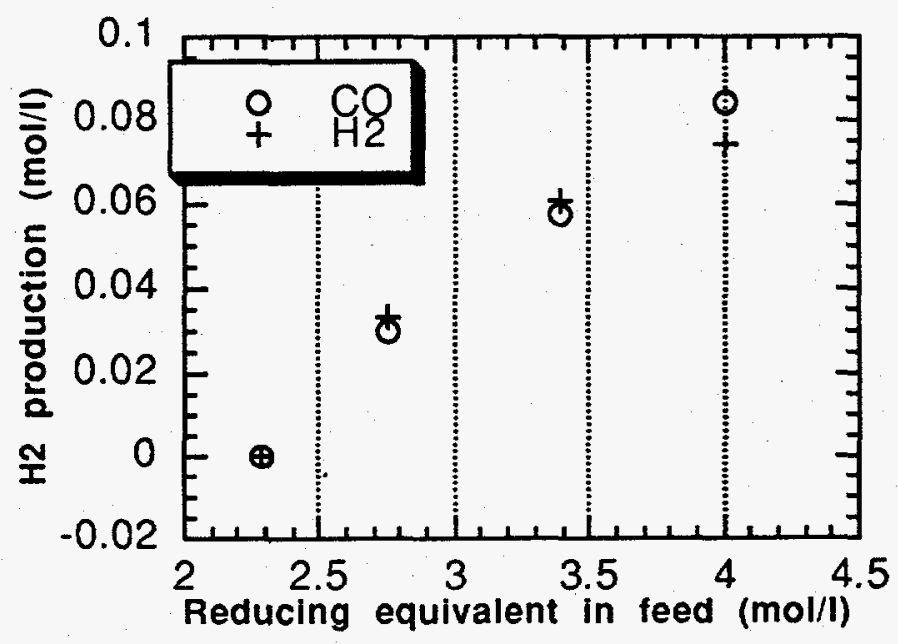

FIGURE 7: Hydrogen and Carbon Monoxide concentrations in effluent for $1 \mathrm{~mol} / \mathrm{h}$ ammonium nitrate with acetic acid at $500^{\circ} \mathrm{C}$ and $345 \mathrm{bar}$ 


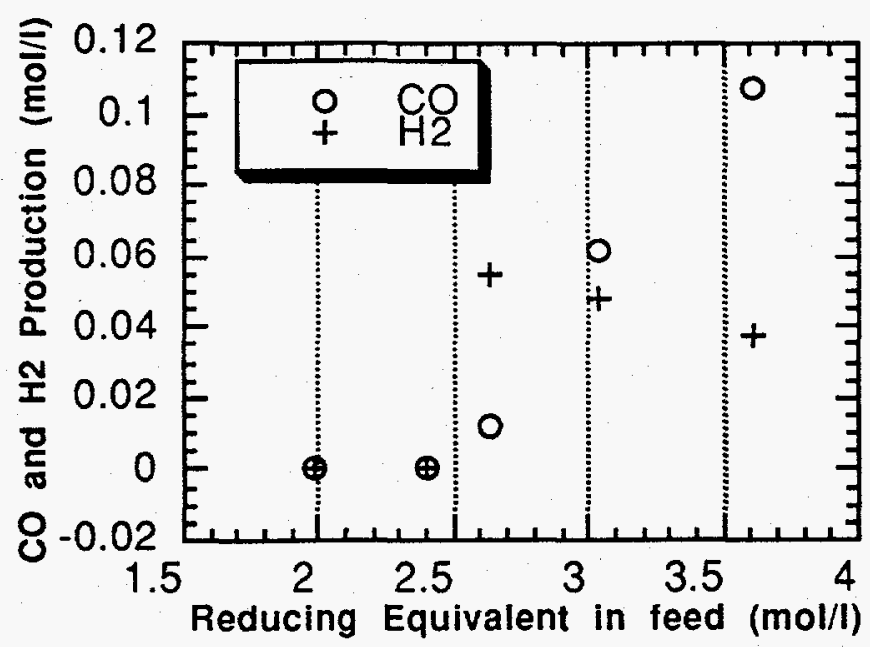

FIGURE 8: Hydrogen and Carbon Monoxide concentrations in effluent for $1 \mathrm{~mol} / \mathrm{l}$ ammonium nitrate with acetic acid at $500^{\circ} \mathrm{C}$ and $345 \mathrm{bar}$

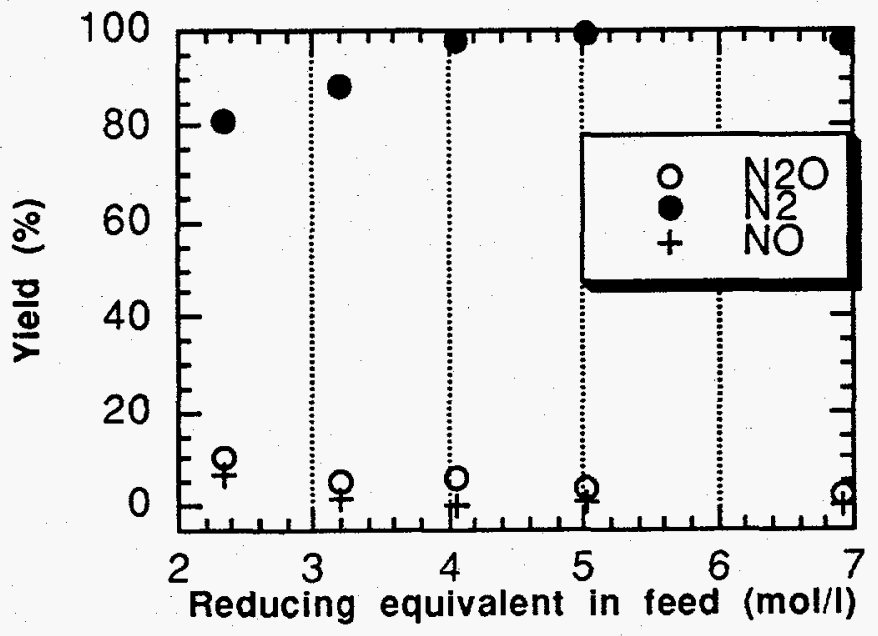

FIGURE 9: Yield of $\mathrm{N}_{2}, \mathrm{~N}_{2} \mathrm{O}$ and $\mathrm{NO}$ for $1 \mathrm{~mol} / \mathrm{h}$ ammonium nitrate with methanol at $500^{\circ} \mathrm{C}$ and 345 bar. 


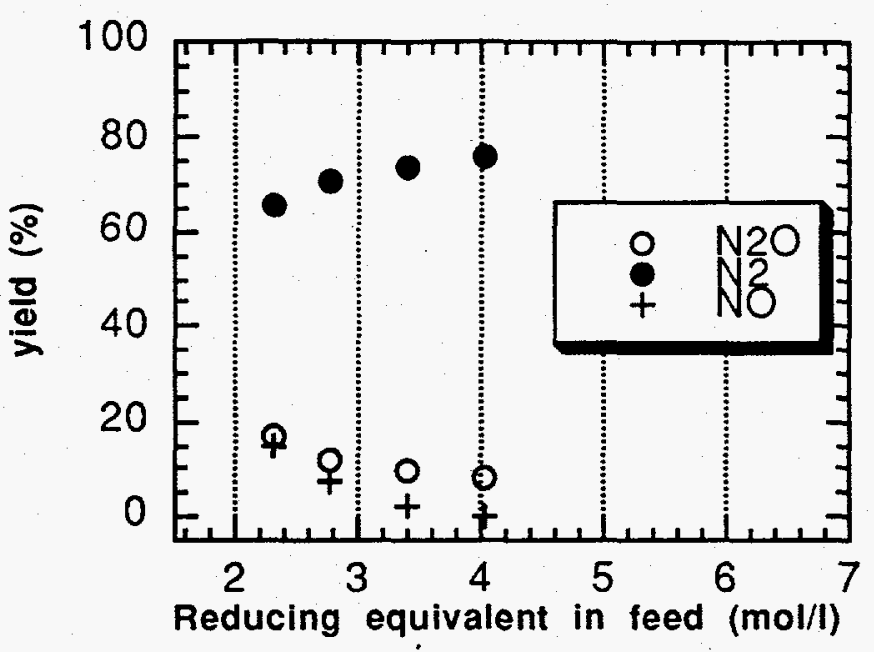

FIGURE 10: Yield of $\mathrm{N}_{2}, \mathrm{~N}_{2} \mathrm{O}$ and $\mathrm{NO}$ for $1 \mathrm{~mol} / \mathrm{l}$ ammonium nitrate with acetic acid at $500^{\circ} \mathrm{C}$ and 345 bar.

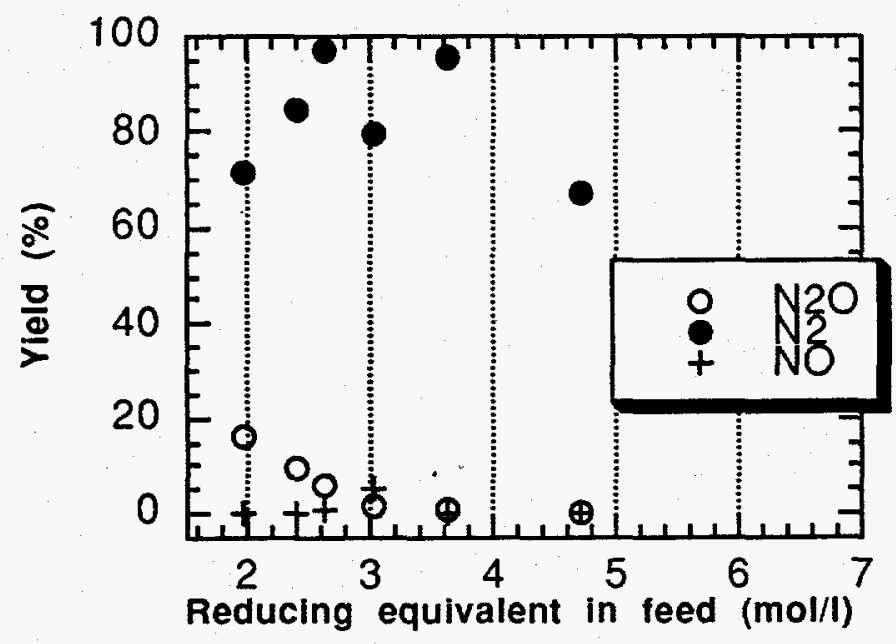

FIGURE 11: Yield of $\mathrm{N}_{2}, \mathrm{~N}_{2} \mathrm{O}$ and $\mathrm{NO}$ for $1 \mathrm{~mol} / 1$ ammonium nitrate with phenol at $500^{\circ} \mathrm{C}$ and 345 bar. 